CLINICAL STUDY

\title{
Variations in urinary iodine excretion and thyroid function. A 1-year study in healthy men
}

\author{
Stig Andersen, Klaus Michael Pedersen, Inge Bülow Pedersen and Peter Laurberg \\ Department of Endocrinology and Medicine, Aalborg Hospital, Reberbansgade, DK-9000 Aalborg, Denmark \\ (Correspondence should be addressed to S Andersen; Email: stiga@dadlnet.dk)
}

\begin{abstract}
Objective: The iodine intake level in a population is determined in cross-sectional studies. A fraction of samples with iodine content below a certain level, e.g. $25 \mu \mathrm{g} / \mathrm{l}$, may suggest iodine deficiency in part of the population. However, urinary iodine varies considerably from day to day and the fraction of low samples caused by dispersion remains unsettled.

Design: A longitudinal study of 16 healthy men living in an area of mild to moderate iodine deficiency. Methods: We measured urinary iodine and creatinine concentrations, and serum TSH, total thyroxine $\left(\mathrm{T}_{4}\right)$, free $\mathrm{T}_{4}$ index and total tri-iodothyronine $\left(\mathrm{T}_{3}\right)$ in samples collected monthly for 1 year. Results: Average urinary iodine excretion was $57.0 \mu \mathrm{g} / \mathrm{l}(49.1 \mu \mathrm{g} / 24 \mathrm{~h}$ (corrected for creatinine excretion)) and varied from 29 to $81 \mu \mathrm{g} / \mathrm{l}(28$ to $81 \mu \mathrm{g} / 24 \mathrm{~h})$ between participants. Individual samples varied between 10 and $260 \mu \mathrm{g} / \mathrm{l}$, and the variation around the mean was 2.4 times larger when calculated for the 180 individual samples compared with the 15 average annual values (1.7 times larger for estimated $24 \mathrm{~h}$ iodine excretion values). The fraction of individual samples below $25 \mu \mathrm{g} / \mathrm{l}$ was $6.7 \%(7.2 \%<25 \mu \mathrm{g} / 24 \mathrm{~h})$, whereas none of the participants had average iodine excretion below $25 \mu \mathrm{g} / \mathrm{l}$ or $25 \mu \mathrm{g} / 24 \mathrm{~h}$. Participants with average annual iodine excretion below $50 \mu \mathrm{g} / 24 \mathrm{~h}$ had a negative correlation between iodine excretion and TSH, whereas a positive correlation was observed when average annual iodine excretion was above this level.

Conclusions: Seven per cent of individual urine samples indicated severe iodine deficiency without this being present in the group studied. Dispersion was reduced by $24 \%$ when using estimated $24 \mathrm{~h}$ urinary iodine excretion rather than urinary iodine concentration. Participants with moderate iodine deficiency (average annual urinary iodine excretion 25-50 $\mu \mathrm{g} / 24 \mathrm{~h}$ ) showed clear signs of substrate deficiency for thyroid hormone synthesis while participants with mild iodine deficiency $(50-100 \mu \mathrm{g} /$ $24 \mathrm{~h})$ did not.
\end{abstract}

European Journal of Endocrinology 144 461-465

\section{Introduction}

The iodine intake level has a marked influence on the incidence and prevalence of thyroid abnormalities in a population $(1,2)$ and iodine exerts a number of effects on the normal and the sick thyroid gland $(3,4)$. The most severe consequences of extremes in iodine intake, with developmental brain damage and endemic goitre, are seen in areas with a very low iodine intake (below 20 or $25 \mu \mathrm{g} /$ day) $(5-7)$. The iodine intake of a population is often assessed by measurements of iodine in urine in cross-sectional studies of selected cohorts (5, 6). This provides information on the average iodine intake and on the frequency of low iodine excretion values. However, in individual subjects urinary iodine excretion to a considerable extent reflects iodine intake over a short period prior to collection $(8-10)$. On the other hand, the thyroid gland has the capacity to store considerable amounts of iodine in thyroglobulin $(4,6)$ and a short period of low iodine intake is not necessarily an indicator of iodine deficiency in a subject.

In areas with severe iodine deficiency the thyroid gland lacks iodine, a main substrate for thyroid hormone synthesis, and an increase in iodine intake causes an increase in thyroid hormone levels in serum and a decrease in serum thyrotrophin (TSH) $(11,12)$. Conversely, in iodine replete areas, an increase in iodine intake causes a decrease in thyroid hormone levels in serum and an increase in serum TSH (13-15) due to autoregulatory iodine inhibition of the thyroid (4). In areas with mild or moderate iodine deficiency, iodine supplementation programmes have been initiated (16) or intensified (17). However, the exact level of iodine intake where the shift between these different mechanisms occur remains unsettled $(5,6)$.

We studied urinary iodine excretion in a group of healthy men living in an area with mild to moderate 
iodine deficiency with monthly sampling for 1 year to approach an estimation of the true iodine excretion level. The aim was to evaluate the relationship between average annual iodine excretion and iodine excretion in single samples. Furthermore, we studied the association between urinary iodine and thyroid function in individual subjects and the importance of average annual iodine excretion for this association.

\section{Subjects and methods}

Sixteen healthy Caucasian men, age 24-52 years (median age 38 years) participated. Participant number 7 had subclinical hyperthyroidism with permanently suppressed serum TSH and normal thyroxine $\left(\mathrm{T}_{4}\right)$, triiodothyronine $\left(\mathrm{T}_{3}\right)$ and free $\mathrm{T}_{4}$ index $(\mathrm{FTI})$ in serum. He was excluded. Of the remaining 15 , none had clinical goitre, and none had previous or present thyroid disorders. All had serum TSH, $\mathrm{T}_{4}, \mathrm{~T}_{3}$ and FTI within the laboratory reference range. None took regular medication or iodine-containing vitamin/mineral preparations. None had undergone examinations with contrast media within 6 months prior to or during the study. Five were non-smokers and 11 present smokers (5-25 cigarettes/day). The characteristics of the individual participants are listed in Table 1.

The participants lived in Jutland, Denmark, where the iodine intake is moderately low (18). We made no restrictions to their daily or yearly routines and sampling procedures were designed to copy the procedures used in cross-sectional studies of urinary iodine excretion to describe the dispersion included in such studies. The study period of 1 year was chosen to include also seasonal differences in the estimate of dispersion. Approval by the regional Ethics Committee was obtained prior to the commencement of this study.

Blood and urine samples were collected monthly for 12 months. A morning (0900 h to $1200 \mathrm{~h})$ blood sample was taken from the cubital vein and a spot urine sample was collected simultaneously from each participant. Serum was promptly separated and samples were stored at $-20{ }^{\circ} \mathrm{C}$ until analyses. All samples from a subject were analysed in the same assay.

\section{Analytical techniques}

Serum TSH was measured using immunochemiluminometric technique and a third generation assay (Brahms, Berlin, Germany). Serum total $\mathrm{T}_{3}$ and serum total $\mathrm{T}_{4}$ were measured by RIAs (Amerlex-M $\mathrm{T}_{3}$ RIA Kit and Amerlex-M $\mathrm{T}_{4}$ RIA Kit, Johnson \& Johnson, Cardiff, UK) and $\mathrm{T}_{3}$ uptake for calculation of FTI using reagents from Farmos Diagnostica, Helsinki, Finland. Urinary creatinine was measured by a kinetic Jaffé method (19). Iodine was determined by the ceri/ arsen method after alkaline ashing (20) as described previously (21) and urinary iodine excretion was expressed in $\mu \mathrm{g} / \mathrm{l}$ or as an estimate of $24 \mathrm{~h}$ urinary
Table 1 Baseline characteristics of individual participants.

\begin{tabular}{lccc}
\hline $\begin{array}{l}\text { Participant } \\
\text { no. }\end{array}$ & $\begin{array}{c}\text { Age } \\
\text { (years) }\end{array}$ & $\begin{array}{c}\text { BMI } \\
\left(\mathrm{kg} / \mathrm{m}^{2}\right)\end{array}$ & $\begin{array}{c}\text { Smoking } \\
\text { (cigarettes/day) }\end{array}$ \\
\hline 1 & 35 & 27.8 & None \\
2 & 28 & 21.5 & 5 \\
3 & 38 & 24.7 & 20 \\
4 & 38 & 26.2 & 25 \\
5 & 38 & 29.0 & None \\
6 & 53 & 26.0 & None \\
7 & 51 & 29.4 & 10 \\
8 & 53 & 21.4 & None \\
9 & 31 & 22.9 & 10 \\
10 & 37 & 23.9 & 20 \\
11 & 26 & 24.5 & 10 \\
12 & 53 & 26.4 & 10 \\
13 & 24 & 21.3 & 20 \\
14 & 32 & 26.2 & 20 \\
15 & 43 & 30.9 & 15 \\
16 & 48 & 24.2 & None \\
\hline
\end{tabular}

iodine excretion. This estimate was based on measurement of creatinine concentration and the average $24 \mathrm{~h}$ urinary creatinine excretion in an age- and gendermatched group of Danes $(1.52 \mathrm{~g} / 24 \mathrm{~h})$ (22) as suggested previously $(23,24)$.

\section{Statistical analysis}

Dispersion was evaluated by $\mathrm{CV} \%$ and interquartile range. Pearson's coefficient of correlation was used to evaluate relations between estimated $24 \mathrm{~h}$ iodine excretion and serum TSH after logarithmic transformation because the distributions were moderately positively skewed, and ANOVA for comparing monthly means. Mann-Whitney $U$ test or paired $t$-test were used for comparison of groups and Kendall's tau was used when testing for a trend in the association between estimated $24 \mathrm{~h}$ urinary iodine excretion and TSH. A $P$ value of less than 0.05 was considered significant. All data were processed and analysed using Corel Quattro Pro 8 and the statistical package for the social sciences (SPSS), version 8.0.

\section{Results}

The average annual urinary iodine concentration (mean of 12 monthly samples) in the 15 participants varied from 29 to $81 \mu \mathrm{g} / \mathrm{l}$ (mean $57.0 \mu \mathrm{g} / \mathrm{l}$; median $50.0 \mu \mathrm{g} / \mathrm{l})$. Iodine concentration in individual urine samples varied from 10 to $260 \mu \mathrm{g} / \mathrm{l}$ and the estimated $24 \mathrm{~h}$ urinary iodine excretions in individual samples varied from 18 to $142 \mu \mathrm{g} / 24 \mathrm{~h}$. The 12 estimated $24 \mathrm{~h}$ urinary iodine excretions for each of the 15 participants are depicted in Fig. 1. They were, in general, low but with considerable individual differences in levels (from 28 to $81 \mu \mathrm{g} / 24 \mathrm{~h}$ ) and variability (CV\% from 20.1 to 70.5 ). The average estimated $24 \mathrm{~h}$ 


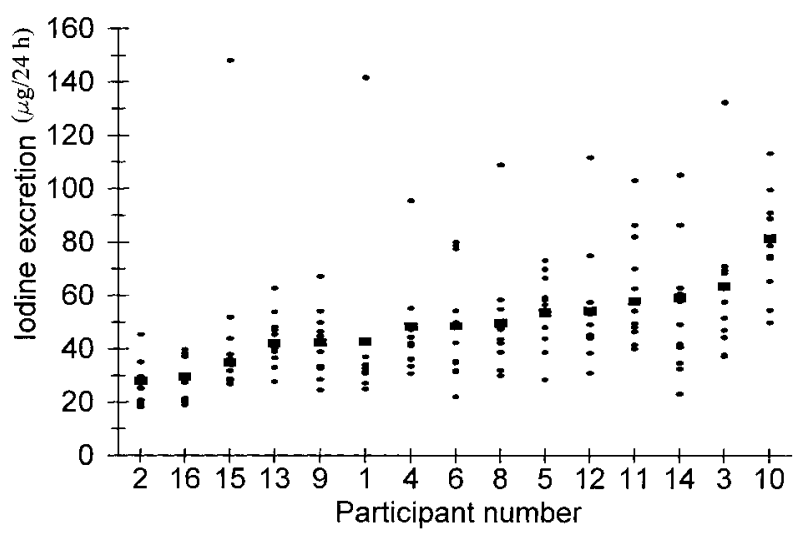

Figure 1 Estimated 24 h urinary iodine excretion in 12 consecutive monthly samples in each of 15 healthy men living in an area with mild to moderate iodine deficiency. Horizontal bars indicate the average estimated $24 \mathrm{~h}$ urinary iodine excretion and each dot represents a monthly estimated $24 \mathrm{~h}$ urinary iodine excretion (corrected for creatinine excretion from an age- and gendermatched group).

urinary iodine excretion was $49.1 \mu \mathrm{g} / 24 \mathrm{~h}$ (median $44.7 \mu \mathrm{g} / 24 \mathrm{~h})$.

If iodine intake was evaluated from individual samples $6.7 \%$ were below $25 \mu \mathrm{g} / \mathrm{l}$ (indicating severe iodine deficiency) and $8.3 \%$ above $100 \mu \mathrm{g} / \mathrm{l}$ (indicating sufficient iodine intake). However, none of the participants had average annual iodine excretion below $25 \mu \mathrm{g} / \mathrm{l}$ or above $100 \mu \mathrm{g} / \mathrm{l}$. A similar difference was observed between estimated $24 \mathrm{~h}$ urinary iodine excretion in individual samples and average annual estimated $24 \mathrm{~h}$ urinary iodine excretion: $7.2 \%$ of single samples $<25 \mu \mathrm{g} / 24 \mathrm{~h} ; 4.4 \%>100 \mu \mathrm{g} / 24 \mathrm{~h}$; none of the average annual values were $<25$ or $>100 \mu \mathrm{g} /$ $24 \mathrm{~h}$.

Table 2 shows calculations of the spread of urinary iodine concentration and of estimated $24 \mathrm{~h}$ urinary iodine excretion for the individual samples and for the average of 12 monthly samples. The variation around the mean urinary iodine concentration was 2.4 times larger when calculated for the 180 individual samples

Table 2 Variation of urinary iodine concentrations and estimated $24 \mathrm{~h}$ urinary iodine excretions in individual samples and in average annual values over 1 year. For comparison they are expressed as both $\mathrm{CV} \%$ and interquartile range.

\begin{tabular}{lcc}
\hline & CV\% & $\begin{array}{c}\text { Interquartile } \\
\text { range }\end{array}$ \\
\hline $\begin{array}{l}\text { Average annual urinary iodine } \\
\text { concentration }(n=15)\end{array}$ & $23.6 \%$ & $11.7 \mu \mathrm{g} / \mathrm{l}$ \\
$\begin{array}{l}\text { Urinary iodine concentration in } \\
\text { individual samples }(n=180)\end{array}$ & $57.3 \%$ & $32.0 \mu \mathrm{g} / \mathrm{l}$ \\
$\begin{array}{l}\text { Average annual estimated } 24 \mathrm{~h} \\
\text { urinary iodine excretion }(n=15)\end{array}$ & $27.0 \%$ & $13.8 \mu \mathrm{g} / 24 \mathrm{~h}$ \\
$\begin{array}{l}\text { Estimated 24 h urinary iodine excretion } \\
\text { in individual samples }(n=180)\end{array}$ & $45.0 \%$ & $23.7 \mu \mathrm{g} / 24 \mathrm{~h}$ \\
\hline
\end{tabular}

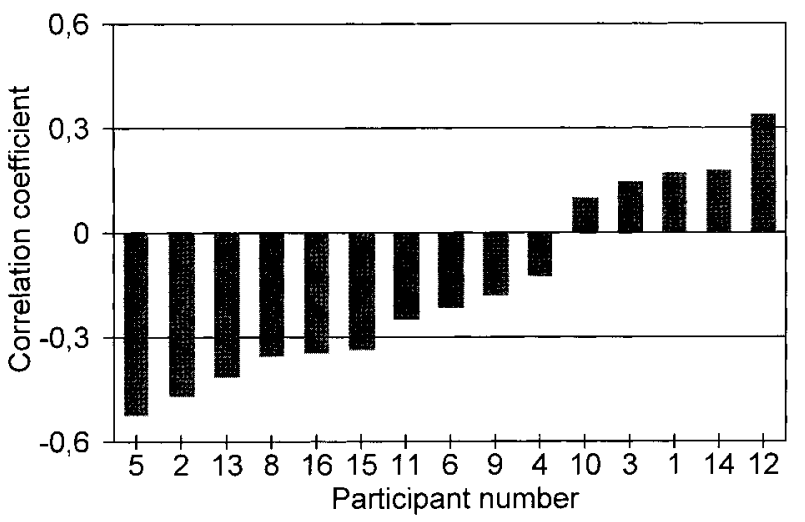

Figure 2 Correlation coefficients between estimated $24 \mathrm{~h}$ urinary iodine excretion and TSH in 15 healthy men with mild to moderate iodine deficiency. Serum and urine samples were collected simultaneously, monthly for 1 year. The $24 \mathrm{~h}$ urinary iodine excretion was calculated from the measured urinary iodine and creatinine in spot urine samples. Correlations are Pearson's correlation coefficients on In-transformed data.

than when calculated for the 15 average annual values (1.7 times larger when estimated $24 \mathrm{~h}$ urinary iodine excretion was used). When using interquartile range, this difference was 2.7 times for urinary iodine concentrations (1.7 times for estimated $24 \mathrm{~h}$ urinary iodine excretion).

Figure 2 shows the coefficients of correlation between estimated $24 \mathrm{~h}$ urinary iodine excretion and thyroid function evaluated by serum TSH in the individual participants. In 10 participants a negative correlation was observed whereas it was positive in five. Samples from participants with a negative correlation showed significantly lower annual urinary iodine excretion (Mann-Whitney $U$ test $P=0.02$ ) and lower $\mathrm{T}_{4}(P=0.02)$ and $\mathrm{T}_{3}$, and a higher $\mathrm{TSH}$ in serum, though the latter did not reach significance (Table 3). This suggested a lower thyroid function in participants with a negative correlation. Furthermore, the correlation between estimated $24 \mathrm{~h}$ urinary iodine excretion and serum TSH showed a significant trend from negative towards positive $(P=0.005)$ when participants were evaluated according to average annual estimated $24 \mathrm{~h}$ iodine excretion. The level for change in this correlation was around $50 \mu \mathrm{g} / 24 \mathrm{~h}$ (Fig. 3).

When comparing monthly means of urinary iodine excretion, serum TSH and thyroid hormones, no statistically significant differences were observed. Between seasons, however, minor differences were observed (ANOVA for iodine excretion, $P=0.077$; for TSH and thyroid hormones, not significant). Estimated $24 \mathrm{~h}$ iodine excretion was higher in spring and summer than in autumn $(23 \%$ and $18 \%)(t$-test, $P=0.02$ and $0.01)$ and winter $(17 \%$ and $12 \%)(P=0.08$ and 0.03$)$. Serum total $\mathrm{T}_{3}$ was $5 \%$ higher in autumn and winter than in summer; serum total $\mathrm{T}_{4}$ was $4 \%$ higher in 
Table 3 Laboratory features of participants with positive and with negative correlation between estimated $24 \mathrm{~h}$ urinary iodine excretion and serum TSH. Results are expressed as mean \pm S.D.

\begin{tabular}{lccc}
\hline & $\begin{array}{c}\text { Positive correlation } \\
(n=5)\end{array}$ & $\begin{array}{c}\text { Negative correlation } \\
(n=10)\end{array}$ & $\boldsymbol{P}$ \\
\hline Average annual urinary iodine excretion $(\mu \mathrm{g} / 24 \mathrm{~h})$ & $60.3 \pm 14.1$ & $43.6 \pm 10.0$ & 0.02 \\
Average annual free $\mathrm{T}_{4}$ index $(\mathrm{nmol} / \mathrm{l})$ & $119.3 \pm 12.9$ & $93.9 \pm 12.8$ & 0.02 \\
Average annual total $\mathrm{T}_{4}(\mathrm{nmol} / \mathrm{l})$ & $123.7 \pm 14.9$ & $97.7 \pm 12.9$ & 0.02 \\
Average annual total $\mathrm{T}_{3}(\mathrm{nmol} / \mathrm{l})$ & $1.78 \pm 0.27$ & $1.57 \pm 0.26$ & $\mathrm{NS}$ \\
Average annual TSH $(\mathrm{mU} / \mathrm{l})$ & $1.12 \pm 0.55$ & $1.35 \pm 0.46$ & $\mathrm{NS}^{\mathrm{a}}$ \\
\hline
\end{tabular}

${ }^{a} \mathrm{NS}=P>0.05$.

autumn and winter than in summer; serum free $T_{4}$ index showed the same pattern but differences were below $2 \%$; serum TSH was $8 \%$ higher in autumn and winter than in spring and summer.

\section{Discussion}

The iodine intake of a population is usually evaluated by measuring urinary iodine excretion in a sample of the population. The most important value obtained is the median or mean urinary iodine concentration or $24 \mathrm{~h}$ urinary iodine excretion $(5,6)$. It has been suggested that not only mean urinary iodine concentration but also the fraction of samples below a certain value is important for evaluation of iodine intake in a population (7).

The results of the present study demonstrate that the distribution of iodine measured in single spot urine samples from a population is much broader than the distribution of average iodine excretion in urine in an individual over 1 year. This implies that a certain per

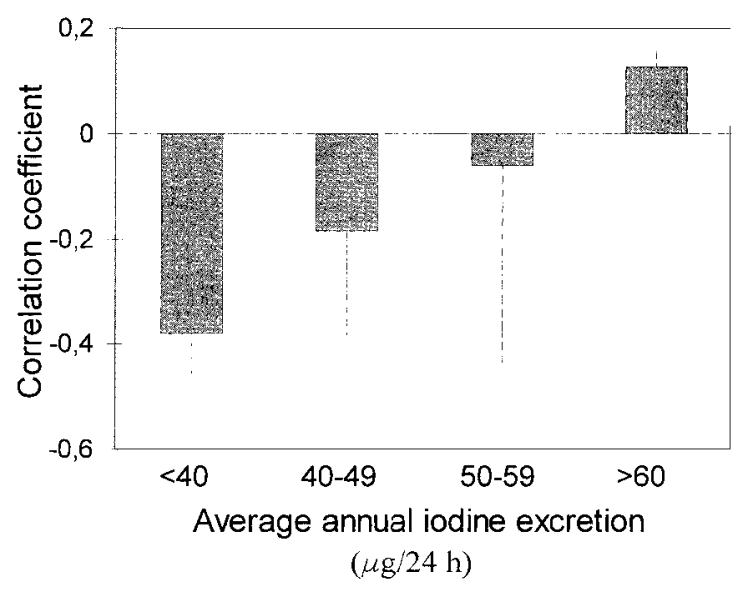

Figure 3 Average correlation coefficients (mean \pm S.E.) between estimated $24 \mathrm{~h}$ urinary iodine excretion and serum TSH in 15 healthy men with mild to moderate iodine deficiency. Participants were grouped according to average annual estimated $24 \mathrm{~h}$ urinary iodine excretion ( $n=3,6,4,2$ in the four groups with increasing iodine excretion). Pearson's correlation coefficients on Intransformed data were used. cent of individual values in the range of, for example, severe iodine deficiency does not necessarily indicate that a similar proportion of the population is severely iodine deficient. In this study $7 \%$ of individual samples were below $25 \mu \mathrm{g} / \mathrm{l}$ while none of the participants had such low iodine excretion when evaluated over 1 year. Under the circumstances of the present study the distribution of average annual values as estimated by CV\% and interquartile range was only $40 \%$ of the distribution of single values. It cannot be excluded, however, that more heterogeneous populations than this may include subgroups with severe iodine deficiency even if the median population iodine excretion is normal. A way to identify subgroups at risk is by evaluation of dietary habits or by repeated measurements of urinary iodine in subjects with low values.

Estimated $24 \mathrm{~h}$ urinary iodine excretion has been preferred to crude urinary iodine excretion by some authors $(23,24)$ as this was more precise in determining the 24-h urinary iodine excretion. In the present study, the use of estimated 24-h iodine excretion reduced the dispersion of measures of iodine excretion by $24 \%$ compared with crude urinary iodine. Such a reduction is especially important when the group investigated is small.

Iodine deficiency is often graded into mild and moderate by urinary iodine excretion above or below $50 \mu \mathrm{g} / 24 \mathrm{~h}(5,6)$. The results of this study imply that this is a reasonable level to use as a separator. The group of subjects investigated lived in an area with mild to moderate iodine deficiency and, by the definition indicated, seven subjects were mildly and eight were moderately iodine deficient. Participants with average annual urinary iodine excretions below $50 \mu \mathrm{g} / 24 \mathrm{~h}$ (moderately iodine deficient) had signs of variation in thyroid function dependent on availability of the substrate iodine, as a distinct negative correlation between urinary iodine and serum TSH was observed. Conversely, subjects with an annual urinary iodine excretion above $50 \mu \mathrm{g} / 24 \mathrm{~h}$ (mildly iodine deficient) had no correlation or a positive correlation between urinary iodine and TSH, suggesting no lack of substrate for thyroid hormone synthesis. Thus, the mechanism by which iodine influences thyroid function changes around $50 \mu \mathrm{g} / 24 \mathrm{~h}$. 
In conclusion, variations in average levels of iodine intake between individuals is much more narrow than indicated by variations between samples obtained in cross-sectional studies. This is important for risk estimation in evaluation of population iodine intake. The present study supports the use of estimated $24 \mathrm{~h}$ urinary iodine excretion rather than measurements of urinary iodine concentration as dispersion was reduced by $24 \%$. Subjects with moderate iodine deficiency evaluated over 1 year showed signs of substrate deficiency for thyroid hormone synthesis, whereas subjects with mild iodine deficiency did not.

\section{Acknowledgements}

We are grateful to Niels Henrik Bruun for his help and advice with the statistical analyses and to Anni Nielsen for technical assistance.

\section{References}

1 Laurberg P, Pedersen KM, Vestergaard H \& Sigurdsson G. High incidence of multinodular toxic goitre in the elderly population in a low iodine intake area vs. high incidence of Graves' disease in the young in a high iodine intake area: comparative surveys of thyrotoxicosis epidemiology in East-Jutland Denmark and Iceland. Journal of Internal Medicine 1991229 415-420.

2 Laurberg P, Pedersen IB, Pedersen KM \& Vestergaard H. Low incidence rate of overt hypothyroidism compared with hyperthyroidism in an area with moderately low iodine intake. Thyroid $1999933-38$.

3 Nagataki S \& Yokoyama N. Autoregulation: effects of iodide. In Verner and Ingbar's the Thyroid: a Fundamental and Clinical Text, pp 241-247. Eds LE Braverman \& RD Utiger. Philadelphia: Lippincott-Raven, 1996.

4 Silva JE. Effects of iodine and iodine-containing compounds on thyroid function. Medical Clinics of North America 198569881 898.

5 Lamberg BA. Iodine deficiency disorders and endemic goitre. European Journal of Clinical Nutrition 199347 1-8.

6 Delange F. The disorders induced by iodine deficiency. Thyroid 19944 107-128.

7 Bordoux P, Delange F, Filetti S, Thilly C \& Ermans AM. Reliability of the iodine/creatinine ratio: a myth? In Thyroid Disorders Associated with Iodine Deficiency and Excess, Serono Symposia Publications, vol 22, pp 145-152. Eds R Hall \& J Köbberling. New York: Raven, 1985.

8 Brussaard JH, Brants HAM, Hulshof KFAM, Kistemaker C \& Löwik MRH. Iodine intake and urinary excretion among adults in the Netherlands. European Journal of Clinical Nutrition $1997 \mathbf{5 1}$ 59-62.

9 Rasmussen LB, Ovesen L \& Christiansen E. Day-to-day and within-day variation in urinary iodine excretion. European Journal of Clinical Nutrition 199953 401-407.

10 Als C, Helbling A, Peter K, Haldimann M, Zimmerli B \& Gerber H. Urinary iodine concentration follows a circadian rhythm: a study with 3023 spot urine samples in adults and children. Journal of Clinical Endocrinology E Metabolism 200085 1367-1369.
11 Tonglet R, Bourdoux P, Minga T \& Ermans AM. Efficacy of low oral doses of iodized oil in the control of iodine deficiency in Zaire. New England Journal of Medicine 1992326 236-241.

12 Azizi F, Kimiagar M, Ghazi AA \& Nafarabadi M. The effects of iodized oil injection in eu- and hypothyroid iodine deficient girls. Journal of Endocrinological Investigations 199720 18-23.

13 Paul T, Meyers B, Witorsch RJ, Pino S, Chipkin S, Ingbar SH et al. The effect of small increases in dietary iodine on thyroid function in euthyroid subjects. Metabolism 198837 121-124.

14 Gardner DF, Centor RM \& Utiger RD. Effects of low dose oral iodide supplementation on thyroid function in normal men. Clinical Endocrinology $1988 \mathbf{2 8} 283-288$.

15 LeMar HJ, Georgitis WJ \& McDermott MT. Thyroid adaptation to chronic tetraglycine hydroperiodide water purification tablet use. Journal of Clinical Endocrinology E Metabolism $199580220-$ 223.

16 Laurberg P, Andersen S, Hreidarsson A, Jørgensen T, Knudsen N, Nøhr S et al. Iodine intake and thyroid disorders in Denmark. Background for an iodine supplementation program. In Elimination of Iodine Deficiency Disorders (IDD) in Central and Eastern Europe, the Commonwealth of Independent States, and the Baltic States, pp 31-46. Eds F Delange, A Robertson, E McLoughney \& G Gerasimov. WHO, Geneva: WHO/EURO/NUT/981, 1998

17 Bürgi H. Iodine deficiency disorders in Switzerland. In Elimination of Iodine Deficiency Disorders (IDD) in Central and Eastern Europe, the Commonwealth of Independent States, and the Baltic States, pp 15-19. Eds F Delange, A Robertson, E McLoughney \& G Gerasimov. WHO, Geneva: WHO/EURO/NUT/981, 1998

18 Pedersen KM, Iversen E \& Laurberg P. Urinary iodine excretion and individual iodine supplementation among elderly subjects: a cross-sectional investigation in the commune of Randers, Denmark. European Journal of Endocrinology 1995132 171-174.

19 Bartels H, Bohmer M \& Heierli C. Serum creatinine determination without protein precipitation. Clinica Chimica Acta 197237 193-197.

20 Wilson B \& van Zyl A. The estimation of iodine in thyroidal amino acids by alkaline ashing. South African Journal of Medical Science 196732 70-82.

21 Laurberg P. Thyroxine and 3,5,3'-triiodothyronine content of thyroglobulin in thyroid needle aspirates in hyperthyroidism and hypothyroidism. Journal of Clinical Endocrinology and Metabolism $198764969-974$.

22 Kampmann J, Siersbæk-Nielsen K, Kristensen M \& Mølholm Hansen J. Rapid evaluation of creatinine clearance. Acta Medica Scandinavia $1974196517-520$.

23 Jolin T \& Escobar del Rey F. Evaluation of iodine/creatinine ratios of casual samples as indices of daily urinary iodine output during field studies. Journal of Clinical Endocrinology and Metabolism 1965 25 540-542.

24 Knudsen N, Christiansen E, Brandt-Christensen M, Nygaard B \& Perrild H. Age- and sex-adjusted iodine/creatinine ratio. A new standard in epidemiological surveys? Evaluation of three different estimates of iodine excretion based on casual urine samples and comparison to $24 \mathrm{~h}$ values. European Journal of Clinical Nutrition $2000 \mathbf{5 4} 361-363$.

Received 5 September 2000

Accepted 22 December 2000 